TAX REFORM

AND THE ALLIANCE FOR PROGRESS 
THIS PAGE INTENTIONALLY LEFT BLANK 
Latin American Monographs, No. 4 Institute of Latin American Studies The University of Texas 
THIS PAGE INTENTIONALLY LEFT BLANK 


\title{
TAX REFORM \\ AND THE ALLIANCE FOR PROGRESS
}

\author{
by Raynard M. Sommerfeld
}

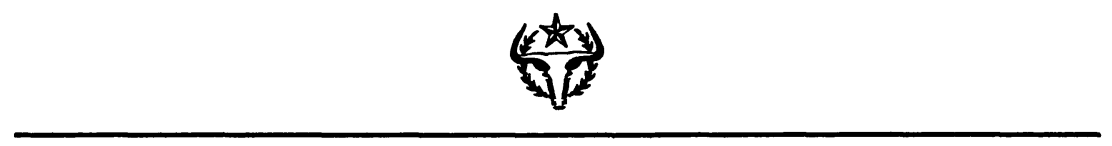

Published for the Institute of Latin American Studies by the University of Texas Press, Austin 
Copyright (C) I 966 by Raynard M. Sommerfeld First paperback printing 2014

All rights reserved

Printed in the United States of America

Requests for permission to reproduce material from this work should be sent to:

Permissions

University of Texas Press

P.O. Box 78 I 9

Austin, TX 787 I3-78I9

http://utpress.utexas.edu/index.php/rp-form

Library of Congress Catalog Number 65-2 I 300

ISBN 978-I-4773-0504-I, paperback ISBN 978-I-4773-0505-8, library e-book ISBN 978-I-4773-0506-5, individual e-book 
To Barb 
THIS PAGE INTENTIONALLY LEFT BLANK 